\title{
Management and Utilization of Pineland Threeawn Range in South Florida
}

\section{RALPH H. HUGHES}

Highlight: Brahman-native cattle grazed cutover forest range in south Florida at the rate of 15,22, and 36 acres per cow per year for 14 years. As the study progressed, the weight of cows increased by 10 to 45 pounds for each decrease in rate of stocking, but all cows tended to calve in alternate years. Weight, quality, and market value of calves increased with each decrease in stocking rate. Income per acre, however, was $\$ 2.50$, $\$ 2.00$, and $\$ 1.25$ for high, medium, and low rates. When sampled 4 months after burning, pineland threeawn, the principal forage species, was most productive on range stocked at the high rate and decreased with decreased stocking. By 19 months after burning, its production was least on range stocked at the high rate and most on that stocked at the low rate. Rate of stocking did not have a significant effect on production of total herbage during either sampling period. Utilization of pineland threeawn at 4 months was 70,60 , and $51 \%$ on range stocked at the high, medium, and low rates. At 7 and 19 months, utilization estimates did not reveal a significant response to rate of stocking. Surveys indicated that no change occurred in condition of the herbaceous vegetation on range stocked at the high rate but that pineland threeawn decreased and other grasses increased on range stocked at the low rate. Shrubby vegetation including saw-palmetto, the principal shrub, increased on range stocked at both high and low rates.

The primary aim of the long-term study reported here was to determine how best to utilize the heavily cutover pinewiregrass ranges which are grazed yearlong by beef cattle in south Florida. Beef production and vegetational response to rates of cattle stocking were observed over a 14-year period.

The study deals mainly with Brahman cattle of the type grown in Florida and with understory vegetation dominated by pineland threeawn (Aristida stricta Michx.) and sawpalmetto (Serenoa repens (Bartr.) Small). Palmettoes constitute the bulk of the vegetation, and pineland threeawn, the common "wiregrass," is the principal species. The wiregrass type is abundant in the piney flatwoods country of Florida and south Georgia. Its total area is approximately 20 million acres.

\section{Study Methods \\ The Study Area \\ The 1,600-acre Caloosa Experimental Range located on the Babcock Florida Company ranch in Charlotte County, Florida,}

The author is range scientist, Southeastern Forest Experiment Station, U.S. Department of Agriculture, Forest Service, Lehigh Acres, Florida. The research reported was a cooperative study by the Southeastern Forest Experiment Station, the Babcock Florida Company, and the Florida Division of Forestry.

Manuscript received August 2, 1973.

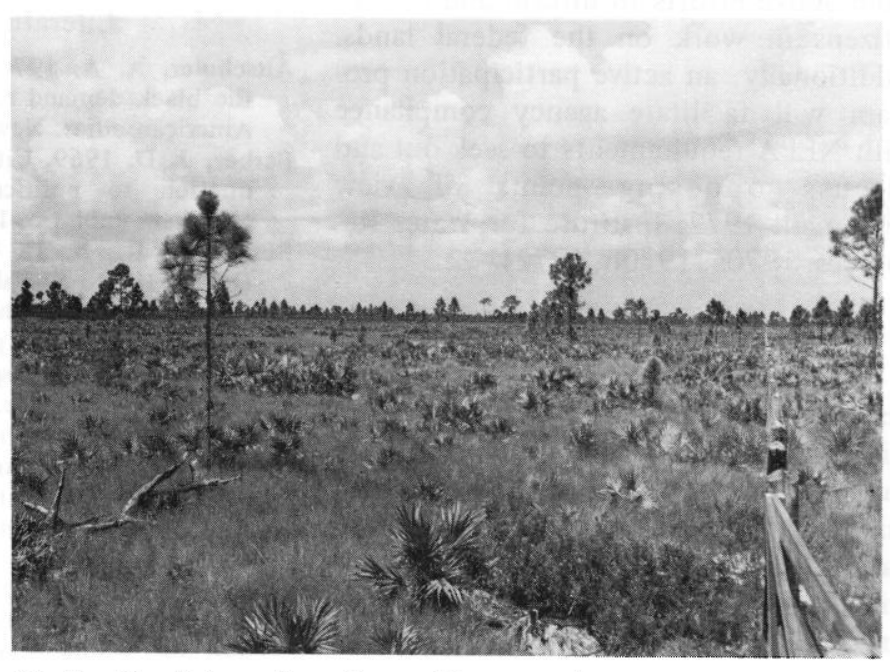

Fig. 1. The Caloosa Experimental Range is characterized by scattered South Florida slash pine, saw-palmetto, occasional other shrubs, and a herbaceous cover dominated by pineland threeawn.

was divided into twelve 90-acre range units, two extra ranges for additional herds of cattle, a headquarters range, and a hospital range. The area is characterized by South Florida slash pine (Pinus elliottii var. densa Little \& Dorman) and sawpalmetto, occasional other shrubs, and numerous herbaceous species of which pineland threeawn is the most abundant (Fig. 1).

The area is typical of the cutover flatwoods of south Florida, with the pine-palmetto type comprising $75 \%$ of the area, wet prairie $10 \%$, and fresh-water marsh, or pond, $15 \%$ (Hilmon, 1964). Clearcutting in the 1940's, followed by frequent burning and close grazing, largely prevented pine regeneration.

Only 12 grasses on the area were rated as good forage: pineland threeawn (new growth only), chalky bluestem (Andropogon capillipes Nash), yellowsedge bluestem ( $A$. virginicus L.), creeping bluestem (A. stolonifer (Nash) Hitchc.), fineleaf bluestem (A. subtenuis Nash), perennial goobergrass (Amphicarpum muhlenbergianum (Schult.) Hitchc.), common carpetgrass (Axonopus affinis Chase), Elliott lovegrass (Eragrostis elliottii S. Wats.), coastal lovegrass (E. refracta (Muhl.) Scrib.), delicate panicum (Panicum chamaelonche Trin.), maidencane (P. hemitomon Schult.), and lopside Indiangrass (Sorghastrum secundum (Ell.) Nash). Of these, pineland threeawn, yellowsedge bluestem, and perennial goobergrass were abundant.

The climate is subtropical with an annual rainfall of about 50 inches occurring largely from June through September. Soils are fine sands, imperfectly drained, with low baseexchange capacity and fertility (Soil Conservation Service, 1962). 


\section{Treatments and Experimental Design}

Three grazing intensities-high, medium, and low-were each replicated twice in a completely randomized design. Within a grazing intensity, two range units were assigned to each replication, with grazing periodically alternating between the two.

The three desired levels of use and expected acres per cow per year needed to attain these levels were as follows:

$\begin{array}{lcc}\text { Rate } & \begin{array}{l}\text { Utilization }(\%) \text { of } \\ \text { pineland threeawn }\end{array} & \begin{array}{c}\text { Acres per } \\ \text { cow per year }\end{array} \\ \text { High } & 65-75 & 15 \\ \text { Medium } & 45-55 & 22 \\ \text { Low } & 30-40 & 36\end{array}$

Utilization of pineland threeawn was taken as the principal consideration on which to base rate of stocking because this species made up over $90 \%$ of the herbage and was the most important species during the critical period of winter grazing. Desired stocking levels were based on pineland threeawn production in the 90-day grazing period after winter burning.

During the first phase, each of six herds of cows were rotated between two range units after burning in alternate years. Six ranges were burned in November of each year, with cattle grazing beginning December 1 for a 2-year cycle. Cattle grazed burned ranges for 7 months (December-February, June-August, and November) and the unburned ranges for 5 months (March-May and September-October) each year.

During the second phase, alternate halves of each range were burned each year in either April or October. Cattle were on the fresh burn May 1 to October 31 or November 1 to April 30 for a 6-month grazing cycle.

\section{Cow-Calf Herds}

Experimental cattle were Brahman-native cows, with calves sired by grade Brahman bulls through 1961 and by Angus bulls thereafter. A 90-day breeding season beginning March 1 was maintained throughout the study.

Range units were stocked initially in 1956 with 4-year-old cows. These were replaced at age 12 in 1963 by 5-year-old cows. Pregnant cows were chosen to be certain of having animals of proven fertility. Of the approximately 50 cows on test, the average cow in 1963 was only 17 pounds heavier than (and in other ways appeared similar to) her 1956 counterpart.

At the beginning of each calibration period, sufficient cows were selected to provide animals for all experimental herds including those necded for adjustment of the stocking rate. As it turned out, very few animals once on grazing schedules were culled or replaced.

In most instances, evaluations of cow performance are based on cows which remained on test the full number of years. Cows continuously on range during the two phases of the study varied from 22 to 23 in pastures stocked at the high rate, 14 to 15 in pastures stocked at the medium rate, and 8 to 10 in pastures stocked at the low rate.

Birth weight of calves was obtained during the 4-year period starting in January 1958. All cattle were weighed at monthly intervals through October 1963 and in May, August, and November thereafter. At monthly intervals in March, April, and May, bulls were rotated between herds and between pastures stocked at the various rates.

Forty-one percent protein in cottonseed pellets was fed as a supplement during September, October, and November 1958-63 and thereafter in February, March, and April and in August, September, and October. Total amounts were about $65 \mathrm{lb}$ per animal unit initially and $120 \mathrm{lb}$ after November, 1963.

A complete salt-mineral was fed on a free-choice basis throughout the year, in sheltered mineral boxes.

During the second phase of the study and apart from the main investigation, an informal study was undertaken on the effect of improved pasture supplement for beef production. For this test, 20 Brahman-Angus cows were split randomly into two herds and assigned to the two "extra" ranges. These cattle had access to 8 acres of study plots fertilized with rock phosphate for 8 months of the year and 10 acres of firebreaks composed of Pensacola bahiagrass (Paspalum notatum var. saurae Perodi.) for 4 months.

\section{Vegetational Surveys}

Quantitative information on the vegetation was obtained by modification of the weight estimate method described by Pechanec and Pickford (1937a, b) and the double sampling procedures described by Wilm et al. (1944). Studies on methodology conducted during the course of the study (Hilmon, 1959; Hilmon et al., 1963) provided adaptations and refinements.

Pine-palmetto upland and wet prairie were surveyed separately. Fresh-water marsh, or pond, was not sampled becausc of sparse vegetaton, flooding, and other inherent sampling difficulties. The upland type was divided into four subunits per range. Two random clusters of four plots, each containing $9.6 \mathrm{ft}^{2}$, were sampled in each subunit. Only two clusters per range were located in the less extensive wet prairie type. The double sampling method was used in obtaining herbage weight for six major species or groups of species on each plot.

During the first phase, plots were established and initial measurements obtained before cattle entered a range and at intervals during a grazing period. Cages were installed to provide ungrazed vegetation. Nearby uncaged plots provided residual or grazed vegetation. Final measurements were made immediately after the end of the grazing period. During the second phase, measurements were taken only when cattle were rotated to different pastures.

Forage production and utilization were sampled at the following times: (1) 4 months after burning over a 4-year period starting in 1957 and (2) 7 and 19 months after burning over a 5-year period starting in 1964.

A total of 63 condition and trend transects were installed in the pine-palmetto type in 1956 and were remeasured in 1961 or 1962. Installation and sampling were according to methods described by Parker (1951) and Parker and Harris (1959). For sampling, four clusters of plots per ecological type were randomly located on aerial photos with a dot grid. All measurements were taken in late summer at least 1 year after range burning.

\section{Results and Discussion}

\section{Forage Production and Utilization}

When sampled 4 months after burning, pineland threeawn was most productive in pastures stocked at the high rate and least productive in those stocked at the low rate. Production of other herbage responded in reverse order such that total herbage production averaged out about the same for all rates. Production at 4 months was less than $400 \mathrm{lb}$ per acre.

At 7 months after burning, rate of stocking did not have a significant effect on production. Pineland threeawn averaged about $500 \mathrm{lb}$ per acre, other grasses $200 \mathrm{lb}$, and total herbaceous vegetation $1,000 \mathrm{lb}$.

At 19 months, the production of pineland threeawn was least in pastures stocked at the high rate and greatest in those stocked at the low rate, whereas the production of other herbage reversed this trend. Hence, as at 4 months but in an opposite direction, the trend of pineland threeawn tended to be offset by the trend of the other herbaceous vegetation such that total production of herbaceous vegetation did not show a significant response to rate of stocking. Total production 
Table 1. Utilization (\%) of selected species and groups of forage species 7 and 19 months after burning in response to rate of stocking, 1964-1968.

\begin{tabular}{|c|c|c|c|c|c|c|}
\hline \multirow[b]{3}{*}{ Species or group } & \multicolumn{6}{|c|}{ Utilization $^{1}$} \\
\hline & \multicolumn{3}{|c|}{7 mos. after burning } & \multicolumn{3}{|c|}{19 mos. after burning } \\
\hline & High & Medium & Low & High & Medium & Low \\
\hline Pineland threeawn & $63^{a}$ & $52^{\mathrm{a}}$ & $46^{\mathrm{a}}$ & $15^{\mathrm{a}}$ & $13^{a}$ & $10^{\mathrm{a}}$ \\
\hline Miscellaneous grasses ${ }^{2}$ & $71^{\mathrm{a}}$ & $59^{\mathrm{ab}}$ & $49^{b}$ & $51^{a}$ & $31^{\mathrm{b}}$ & $7^{\mathrm{c}}$ \\
\hline Total grasses & $65^{\mathrm{a}}$ & $56^{\mathrm{ab}}$ & $45^{\mathrm{b}}$ & $30^{\mathrm{a}}$ & $20^{\mathrm{ab}}$ & $14^{b}$ \\
\hline Grasslikes & $57^{\mathrm{a}}$ & $25^{\mathrm{b}}$ & $13^{c}$ & $28^{\mathrm{a}}$ & $13^{\mathrm{ab}}$ & $8^{b}$ \\
\hline Forbs & $61^{\mathrm{a}}$ & $47^{a b}$ & $40^{\mathrm{b}}$ & $25^{\mathrm{a}}$ & $22^{\mathrm{ab}}$ & $7^{b}$ \\
\hline Total herbage & $59^{\mathrm{a}}$ & $52^{\mathrm{a}}$ & $41^{\mathrm{a}}$ & $31^{\mathrm{a}}$ & $17^{\mathrm{a}}$ & $10^{\mathrm{a}}$ \\
\hline
\end{tabular}

${ }^{1}$ Within a time period for a particular species or group, means followed by the same letter are not significantly different at the $5 \%$ level by Duncan's multiple range test.

${ }^{2}$ All grasses other than pineland threeawn.

varied from 1,350 to $1,500 \mathrm{lb}$ per acre.

Some herbage is produced year-round, but season of burning has a profound effect on herbage growth. When measured at 7 months, range burned in the spring contained about twice as much growth as range burned in the fall. These results are in accord with those from other studies which had shown that forage yield is influenced markedly by growing season and month in which the range is burned (Lewis, 1964).

$\Lambda$ fter a recovery period of 19 months, however, season of burning had little or no effect on production, with a few exceptions. Grasslike species were almost twice as productive on range burned in the spring, whereas miscellaneous grasses were slightly more productive on range burned in the fall.

Total production at 7 months averaged $600 \mathrm{lb}$ on range burned in the fall and 1,300 lb on range burned in the spring; a year later, it averaged $1,400 \mathrm{lb}$, regardless of season of burn. During both years, more than half the herbaceous vegetation was composed of pineland threeawn, regardless of whether the range was burned in the spring or in the fall.

When measured in March, 4 months after burning, utilization of pineland threeawn was somewhat higher than planned on ranges with medium and low rates of stocking: $51 \%$ at the low rate, $60 \%$ at the medium rate, and $70 \%$ at the high rate. Utilization of total herbaceous vegetation averaged $46 \%$ at the low rate, $54 \%$ at the medium rate, and $66 \%$ at the high rate. These trends seemed to indicate that using pineland threeawn to adjust stocking rate probably did not reflect true grazing pressure.

Comparable estimates 7 and 19 months after burning did not reveal a significant response to rate of stocking. Lack of response was attributed to declining palatability of the wiregrass-type vegetation was time after burning.

For several species and groups, however, utilization at 7 and 19 months did vary by rate of stocking (Table 1). The most sensitive of these appeared to be grasslike species on first-year rough ( 7 months' growth) and miscelianeous grasses on rough burned the year previously (19 months' growth).

Because grasses comprised the bulk of the herbaceous vegetation, estimates of their use probably approximated actual range use most closely. Approximations of the use levels (\%) necessary to achicve the three rates of stocking during the first and second years after burning were as follows:

$\begin{array}{lccc} & \text { High } & \text { Medium } & \text { Low } \\ \text { First year } & 65 & 55 & 45 \\ \text { Second year } & 30 & 20 & 10\end{array}$

Apart from the effect of rate of stocking, utilization of pineland threeawn 7 months after burning averaged $67 \%$ on halves of ranges burned in October and only $40 \%$ on halves burned in April. Utilization (\%) of species and groups with a similar trend during the first year was as follows:

$\begin{array}{lcc} & \text { Fall burn } & \text { Spring burn } \\ \text { Pineland threeawn } & 67 & 40 \\ \text { Total grasses } & 62 & 48 \\ \text { Total herbs } & 57 & 45 \\ \text { Saw-palmetto } & 39 & 0 \\ \text { Other shrubs } & 42 & 3\end{array}$

Samples collected 19 months after burning indicated that use of pineland threeawn had dropped sharply on ranges burned in both spring and fall and averaged only 13\%. All other sampled species and groups responded similarly.

\section{Composition of Vegetation}

Percentages of the total herbage provided by pineland threeawn 4, 7, and 19 months after burning on ranges stocked at the various rates were as follows:

\begin{tabular}{ccccc} 
& & \multicolumn{3}{c}{ Stocking rates } \\
Months after burning & Years sampled & High & Medium & Low \\
4 & $1957-60$ & $46^{\mathrm{a}}$ & $45^{\mathrm{a}}$ & $42^{\mathrm{b}}$ \\
7 & $1964-68$ & $47^{\mathrm{a}}$ & $55^{\mathrm{a}}$ & $55^{\mathrm{a}}$ \\
19 & $1964-68$ & $46^{\mathrm{a}}$ & $53^{\mathrm{a}}$ & $62^{\mathrm{b}}$
\end{tabular}

(Within each time period after burning, means followed by the same letter are not significantly different at the 5\% level by Duncan's multiple range test.) The large increase between 4 and 19 months on pastures stocked at the low rate was apparently due to little or no use of pineland threeawn and to the continuing growth habit of this species. In a 2-year burning cycle, grazing of pineland threeawn is limited almost entirely to early spring of the first year-growth becomes wiry and unpalatable by May or June (Leithead et al., 1971). Conversely, the advantage that other species had on freshly burned pastures stocked at the low rate diminished rapidly with time from burning.

An inspection of annual rainfall records ${ }^{1}$ during the period of study indicated that pineland threeawn responded adversely to heavy precipitation. Throughout its distribution, this grass is known to thrive on deep sands and yet to withstand considerable flooding. The highest percentage of pineland threeawn (60) occurred with the least rainfall (33 inches), and the least percentage (47) occurred with the most rainfall (70 inches).

The best time to assess composition was soon after burning, insofar as variability between samples was concerned. In harvests 4 months after burning, the coefficient of variation was much less than in subsequent harvests: 4 months, $3.2 \% ; 7$ months, $30.8 \%$; and 19 months, $20.4 \%$.

On condition and trend transects, percentage of cover provided by herbaceous vegetation in range stocked at the low rate increased from 25 to 35 over a 5-year period (Table 2). Pineland threeawn meanwhile decreased from 11 to $8 \%$ cover, and other grasses-among them bluestems and panicumsincreased from 10 to $18 \%$. Grasslikes also underwent a significant increase.

Cover remained mostly unchanged (near $25 \%$ ) on the range stocked at the high rate. The static (statistically unchanged)

\footnotetext{
${ }^{1}$ Environmental Data Service, U.S. Department of Commerce, Fort Myers, Florida, Weather Station.
} 
Table 2. Trend in ground cover $(\%)$ on range stocked at the high and low rates. ${ }^{1}$

\begin{tabular}{lrrrrr}
\hline & \multicolumn{3}{c}{ Ground cover } \\
\cline { 2 - 3 } \cline { 2 - 3 } Item & \multicolumn{2}{c}{ High rate } & & \multicolumn{2}{c}{ Low rate } \\
\cline { 2 - 3 } \cline { 2 - 3 } & 1956 & 1962 & & 1956 & 1961 \\
\hline Herbaceous vegetation & 25 & 27 & & 26 & 35 \\
Bare soil & 65 & 53 & & 43 & 30 \\
Litter & 9 & 18 & & 26 & 28 \\
Saw-palmetto rhizomes & 1 & 2 & & 5 & 7 \\
$\quad$ Total & 100 & 100 & & 100 & 100 \\
\hline
\end{tabular}

${ }^{1}$ Upland 2-year rough of pine-palmetto inventoried in August and September. Average of 27 transects in range unit 1 (high rate) and 36 transects in range unit 8 (low rate).

condition more or less characterized all herbaceous components. These results, together with those obtained in the production-utilization surveys, indicate that the range was not damaged by frequent burning and heavy grazing. Low palatability provides a natural rest from grazing between burns, and this rest obviously enables wiregrass-type range to maintain vigor under continuous year-round use.

This response is contrary to the responses reported by Halls et al. (1956) for wiregrass ranges in south Georgia with light $(30 \%)$, moderate $(44 \%)$ and heavy $(65 \%)$ utilization of herbage. There, pineland threeawn showed its greatest decline on ranges moderately to heavily grazed and a slight increase on lightly grazed ranges. These findings, however, were influenced by a tree overstory which was mostly absent in the present study and by major differences in site quality.

Shrubby vegetation increased with time on range stocked at both the light and heavy rates: $31 \%$ at the high rate and $13 \%$ at the low rate. Saw-palmetto increased by $42 \%$ on range stocked at the high rate and by $15 \%$ on range stocked at the low rate.

As a group, the shrubs, though not generally palatable to livestock, included several species that are important to wildlife, especially deer (Harlow, 1961) and quail (Laessle and Frye, 1956). Important species were mainly dwarf waxmyrtle (Myrica pusilla Raf.), ground blueberry (Vaccinium myrsinites Lam.), gallberry (Ilex glabra (L.) A. Gray), and saw-palmetto. Fruits of saw-palmetto are relished by deer and turkey (Schemnitz, 1956).

Composition of the vegetation grazed at the high rate (Table 3) generally reflected the static condition recorded for herbaceous cover (Table 2). This similarity was expected because the history of the experimental area is known to be one of frequent burning and heavy use by livestock. Pineland

Table 3. Composition (\%) of herbaceous vegetation in 1956 and 1962 on range stocked at the high rate and in 1956 and 1961 on range stocked at the low rate.

\begin{tabular}{|c|c|c|c|c|}
\hline \multirow[b]{3}{*}{ Species or group } & \multicolumn{4}{|c|}{ Composition } \\
\hline & \multicolumn{2}{|c|}{ High rate } & \multicolumn{2}{|c|}{ Low rate } \\
\hline & 1956 & 1962 & 1956 & 1961 \\
\hline Pineland threeawn & 38 & 31 & 37 & 22 \\
\hline Bluestems & 3 & 3 & 3 & 8 \\
\hline Panicums & 18 & 15 & 23 & 29 \\
\hline Other grasses & 10 & 9 & 19 & 14 \\
\hline Grasslikes & 23 & 29 & 13 & 19 \\
\hline Forbs & 8 & 13 & 5 & 8 \\
\hline Total & 100 & 100 & 100 & 100 \\
\hline
\end{tabular}

\footnotetext{
${ }^{1}$ Upland 2-year rough of pine-palmetto inventoried in August and September on 27 transects in range unit 1 (high rate) and 36 transects in range unit 8 (low rate).
}

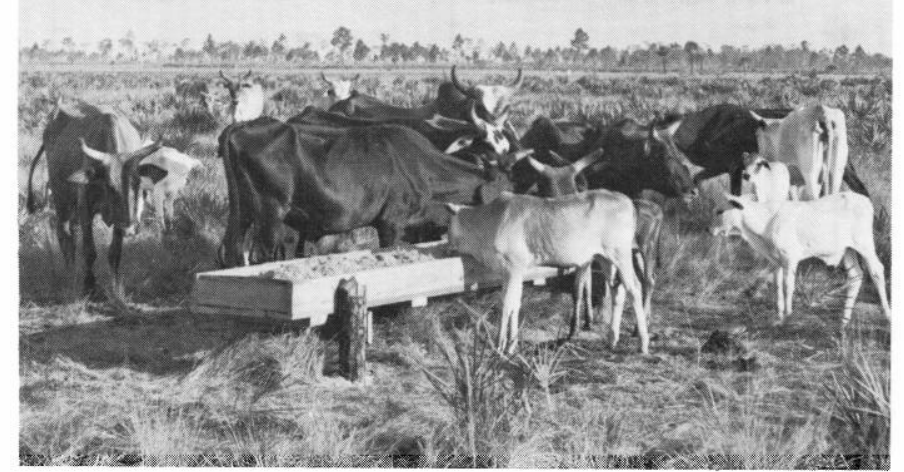

Fig. 2. Improvements in beef production were noted when fresh burns were available twice a year, calves were weaned a month earlier, and supplemental feeding was increased from 65 to $125 \mathrm{lb}$ per year.

threeawn and the panicums decreased insignificantly on this range, and the bluestems were unchanged.

There were compositional changes, however, in the range grazed at the low rate. Both bluestems and panicums increased, whereas pineland threeawn decreased sharply. Common among the bluestems were three species rated as good forage by Hilmon (1964): chalky bluestem, yellowsedge bluestem, and creeping bluestem. The panicums as a group produce high-quality forage, though in limited amounts; they also produce some green feed for cattle during the winter and comprise an array of species important to wildlife, especially quail (Laessle and Frye, 1956).

\section{Calf Production}

Over a 10-year period, percentage of weaned calves averaged 48 on range stocked at the high rate, 54 on range stocked at the medium rate, and 50 on range stocked at the low rate. Differences between rates were not significant. Cows tended to calve in alternate years, regardless of stocking. Of the 231 instances of cows suckling calves, for example, only 14 (or 6\%) involved calving in two successive years. Conversely, of the 166 cows that were dry during a breeding season, 149 weaned a calf in the succeeding year.

The overall diet of native forage obviously did not meet nutritional requirements for cows suckling calves. Cows calving in successive years averaged $20 \mathrm{lb}$ lighter on the second weaning date than on the preceding one. The second calves, too, were smaller than those of the preceding year, by $50 \mathrm{lb}$.

Calf losses were substantial-more than $6 \%$ of the known conceptions. Losses were greatest among herds in the high rate of stocking. Twelve of the total of 16 losses, including 9 of the 10 calves classified as too weak to suckle, were from herds stocked at the high rate.

Cows weaning calves averaged $48 \%$ during the first phase of the study and $55 \%$ during the second phase. The improvement, though meager, probably reflects interim management changes such as availability of fresh burns twice a year, increase in level of supplemental feeding from 65 to $125 \mathrm{lb}$, and the 1-monthearlier date for calf weaning (Fig. 2).

Throughout the study, weaning weights were significantly less on range stocked at the high rate (Table 4). Birth weights-either actual or after adjustments for sex-were similar and averaged $55 \mathrm{lb}$. Cows stocked at the high rate calved later than the others during the period 1958-1963 but not after the management change. Thus, lower weaning 


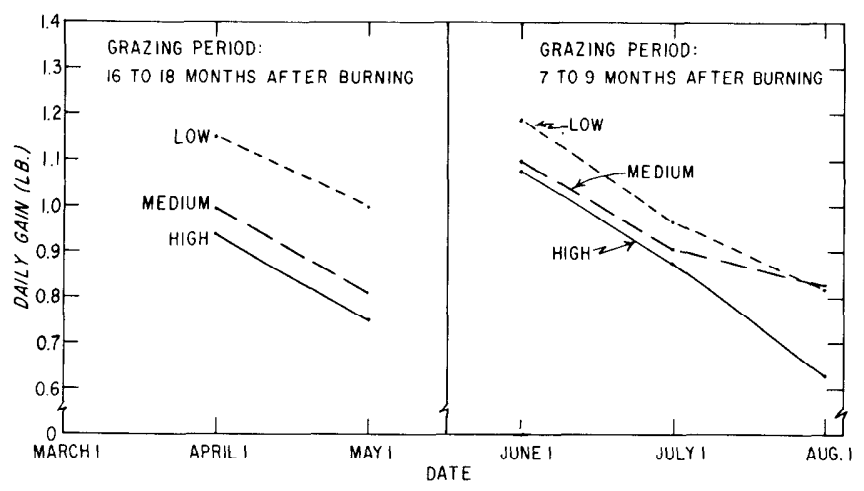

Fig. 3. Average daily gain of calves at the three rates of stocking during the 4-year period from April, 1958, through August, 1961.

weights at high stocking were primarily attributable to daily gain, which was significantly less than at low stocking.

Growth of calves at all stocking levels was related to time after burning (Fig. 3). Rate of gain decreased from April to May as time after burning increased from 16 to 18 months, increased sharply in June following the shift of cattle to more recently burned range on June 1 , and then declined in July and August on range grazed 7 to 9 months after burning. On wiregrass range burned in winter, it is usual for calves to gain most rapidly in the spring, continue to gain at a slightly reduced rate through the summer, and then gain less rapidly in the fall (Southwell and Hughes, 1965).

Quality of calves, as well as their size, was undoubtedly influenced by the different stocking rates and management practices applied during the two phases of the study. Slaughter grades increased with each decrease in the stocking rate-from high utility to medium standard during the first phase and from low standard to high standard during the second phase (Table 5). In terms of dollar value per pound of beef, the change was not great, averaging less than $\$ 2$ per $100 \mathrm{lb}$ between high and low rates and less than $\$ 1$ per $100 \mathrm{lb}$ between phases of the study.

Sale price per calf increased conversely with rate of stocking (Table 6), as did size (Table 4) and slaughter grade (Table 5). The increases were considerable, amounting to $\$ 17$ per calf during the first phase and $\$ 25$ per calf during the second phase. On a per-acre basis, however, the response was reversed; income increased with each increase in rate of stocking. Again, the differences between rates were considerable-as much as $\$ 1(83 \%)$ per acre per year.

The change in management practices also had an apparent beneficial effect on value of weaned calves as well as cash return per acre. Practices begun in 1964 were followed by an increase from $\$ 82$ to $\$ 89$ per calf and from $\$ 1.76$ to $\$ 2.12$ per acre. Even so, the dominant factor influencing income was the

Table 4. Age (days), weaned weight (lb), and daily gain (lb) of calves from birth to weaning on range stocked at three rates. ${ }^{1}$

\begin{tabular}{|c|c|c|c|c|c|c|}
\hline \multirow{3}{*}{$\begin{array}{l}\text { Rate of } \\
\text { stocking }\end{array}$} & \multicolumn{6}{|c|}{ Study phases } \\
\hline & \multicolumn{3}{|c|}{$1958-1963$} & \multicolumn{3}{|c|}{$1965-1969$} \\
\hline & Age & Weight & Daily gain & Age & Weight & Daily gain \\
\hline $\begin{array}{l}\text { High } \\
\text { Medium } \\
\text { Low }\end{array}$ & $\begin{array}{l}228^{a} \\
239^{b} \\
237^{b}\end{array}$ & $\begin{array}{l}288^{a} \\
321^{b} \\
341^{c}\end{array}$ & $\begin{array}{l}0.96^{\mathrm{a}} \\
1.05^{\mathrm{ab}} \\
1.15^{\mathrm{b}}\end{array}$ & $\begin{array}{l}204^{\mathrm{a}} \\
200^{\mathrm{a}} \\
207^{\mathrm{a}}\end{array}$ & $\begin{array}{l}299^{a} \\
335^{a b} \\
368^{b}\end{array}$ & $\begin{array}{l}1.21^{\mathrm{a}} \\
1.41^{\mathrm{b}} \\
1.53^{\mathrm{b}}\end{array}$ \\
\hline Average & 235 & 317 & 1.05 & 204 & 334 & 1.38 \\
\hline
\end{tabular}

${ }^{\mathrm{I}}$ Within a column, means followed by the same letter are not significantly different at the $5 \%$ level by Duncan's multiple range test.

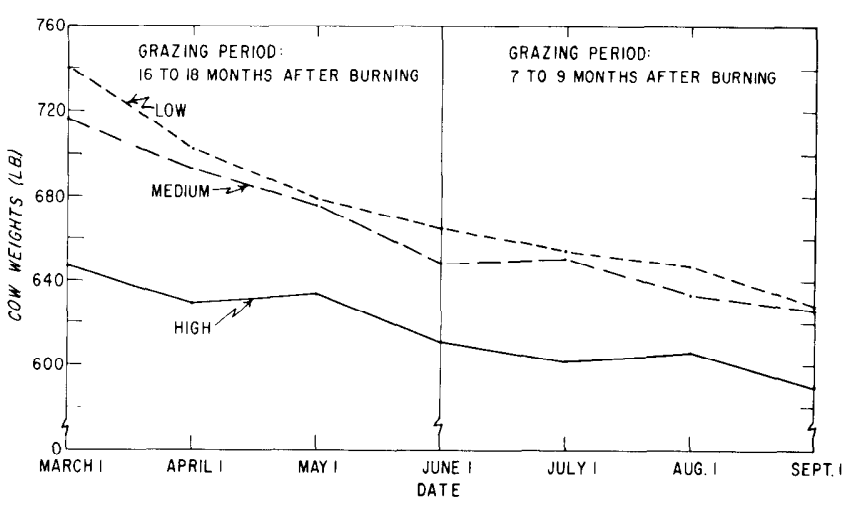

Fig. 4. Cumulative weight changes of cows suckling calves at the three rates of stocking during the 4-year period from March, 1958, to September, 1961.

tendency of all cows to calve in alternate years.

Substantially increased beef production was provided by cattle on range supplemented with improved pasture. South Florida is well suited to the production of improved pasture, and this is one of the most economical methods of furnishing most of the nutrients needed by beef cows (Chapman and Kirk, 1968). As an example, the following tabulation compares beef production on ranges grazed at the high rate of stocking and on comparably grazed range supplemented with limited pasture:

Cow crop (1965-69) (\%)

Weaned weight of calves (lb)

Sale price per pound (cents)

Value of beef per cow (dollars)

With pasture Without pasture

$\begin{array}{rr}71 & 52 \\ 360 & 300 \\ 27 & 26 \\ 69 & 41\end{array}$

\section{Condition of Cows}

Weight of cows suckling calves followed a definite pattern with respect to rate of stocking in the 4 years, 1958-1961, when weights were taken at monthly intervals (Fig. 4). Throughout the spring and summer, lactating cows stocked at the low rate were heavier than those stocked at the medium rate, and those stocked at the medium rate were heavier than those stocked at the high rate. Weight differences averaged about $10 \mathrm{lb}$ between cows stocked at the low and medium rates and $45 \mathrm{lb}$ between cows stocked at the medium and high rates. Although there was a downward trend in weights of all cows from March through August, losses were greater before July than afterward.

This downward trend in weight as the seasons progressed paralleled the elapsed time after burning: from the 16th through the 18th month during the spring and from the 7 th through the 9 th month during the summer. The older rough undoubtedly had an adverse affect on condition of cattle.

Table 5. Slaughter grade and sale price (dollars/cwt) on weaning date of calves on range stocked at three rates. ${ }^{1}$

\begin{tabular}{|c|c|c|c|c|}
\hline \multirow{3}{*}{$\begin{array}{l}\text { Rate of } \\
\text { stocking }\end{array}$} & \multicolumn{4}{|c|}{ Study phases } \\
\hline & \multicolumn{2}{|l|}{$1958-1963$} & \multicolumn{2}{|l|}{$1965-1969$} \\
\hline & Grade & Sale price ${ }^{2}$ & Grade & Sale price ${ }^{2}$ \\
\hline High & High utility ${ }^{\mathrm{a}}$ & $25.30^{\mathrm{a}}$ & Low standard ${ }^{\mathrm{a}}$ & $25.70^{\mathrm{a}}$ \\
\hline Medium & Low standard $\mathrm{d}^{\mathrm{ab}}$ & $26.00^{\mathrm{b}}$ & Medium standard ${ }^{a}$ & a $26.10^{\mathrm{a}}$ \\
\hline Low & Medium standard $b$ & b $26.50^{c}$ & High standard ${ }^{b}$ & $27.65^{b}$ \\
\hline
\end{tabular}




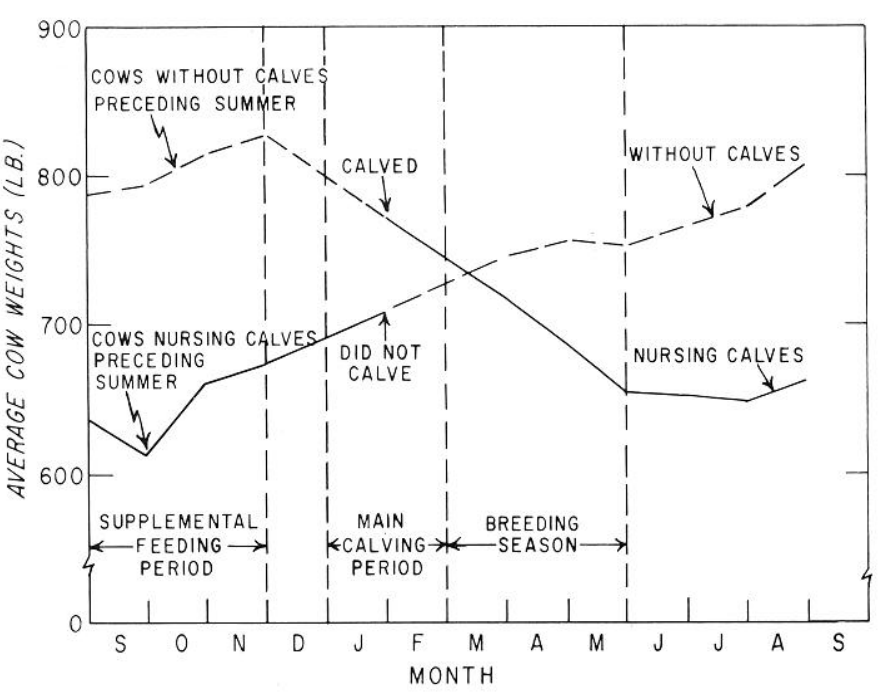

Fig. 5. Seasonal trend in weights of cows with calves and those without calves, 1958-1963 (average of six herds for 5 years).

Chemical analyses of forage samples collected during the course of the study had shown a continuing decline in nutritive content with elapsed time after burning (Hilmon and Lewis, 1962).

Weight losses during the winter averaged more than $100 \mathrm{lb}$ for cows that calved (Fig. 5). These losses represent birth weight of the calf and other losses incidental to calving. By breeding time, cows suckling calves had regained only a small proportion of the loss, regardless of the assigned stocking rate. During the breeding period, these cows were generally losing or else barely maintaining their weight.

Dry cows-those that nursed calves the preceding summerwere in very poor condition at the start of the supplemental feeding period. They gained during this period and continued to gain during the breeding season.

Almost identical seasonal trends as those noted above persisted after revision of the plan of cattle management in 1964. Weights and weight changes of cows with and without calves followed a similar pattern.

Death losses among cows averaged $2 \%$ per year but did not appear to be correlated with rate of stocking. The one loss from starvation, as well as the two losses of weak cows bogged in a pond, however, occurred in pastures stocked at the high rate.

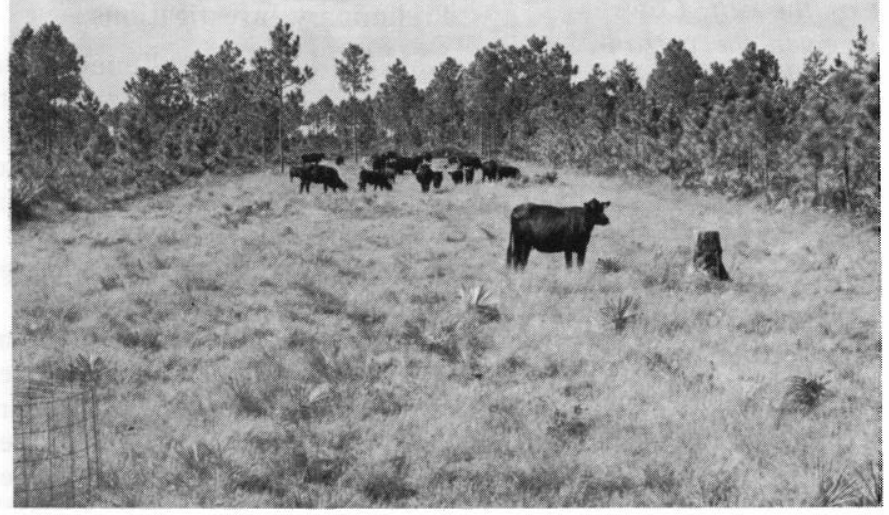

Fig. 6. Substantially increased beef production was provided by cattle on range supplemented with improved pasture.
Table 6. Sale value (dollars) per calf and total value (dollars) of calves per acre per year from ranges stocked at three rates. ${ }^{1}$

\begin{tabular}{|c|c|c|c|c|}
\hline \multirow{3}{*}{$\begin{array}{l}\text { Rate of } \\
\text { stocking }\end{array}$} & \multicolumn{4}{|c|}{ Study phases } \\
\hline & \multicolumn{2}{|c|}{$1958-1963$} & \multicolumn{2}{|c|}{ 1965-1969 } \\
\hline & Dollars/calf ${ }^{2}$ & Dollars/acre ${ }^{2}$ & Dollars/calf ${ }^{2}$ & Dollars/acre ${ }^{2}$ \\
\hline High & $73^{\mathrm{a}}$ & $2.17^{\mathrm{a}}$ & $77^{\mathrm{a}}$ & $2.64^{\mathrm{a}}$ \\
\hline Medium & $83^{b}$ & $1.89^{\mathrm{a}}$ & $87^{b}$ & $2.28^{\mathrm{b}}$ \\
\hline Low & $90^{\mathrm{c}}$ & $1.22^{\mathrm{b}}$ & $102^{\mathrm{c}}$ & $1.44^{\mathrm{c}}$ \\
\hline Average & 82 & 1.76 & 89 & 2.12 \\
\hline
\end{tabular}

${ }^{1}$ Within a column, means followed by the same letter are not significantly different at the $5 \%$ level by Duncan's multiple range test.

${ }^{2}$ Based on Florida Weekly Livestock Market Summary, Wauchula market, July 31, 1969.

In contrast, cows with access to both range and pasture in the supplemental study were consistently heavier thar cows with access only to range, despite higher percentages of calving for the former (Fig. 6). Among cows that calved, those with range plus limited pasture weighed $80 \mathrm{lb}$ more than their counterparts in May and $60 \mathrm{lb}$ more in August.

\section{Conclusion}

Guides to better utilization of wiregrass range were obtained through observations on effect of rate of stocking and season of burning. The most palatable forage species, particularly bluestems and panicums, were favored by reduction in rate of stocking. Cattle continued to select these species throughout the growing season and leave pineland threeawn to mature and complete its growth requirements. Two of the bluestems, chalky bluestem and creeping bluestem, are among the most valuable native grasses in Florida. They provide excellent forage yearlong and are also excellent for winter roughage when supplemented with protein.

Weight changes of cattle emphasize the limited quality of the native forage. Even with a reduced rate of stocking such that the amount of wiregrass forage per animal is not limiting, the native range apparently needs to be supplemented with other forage or feed much of the year if a high level of herd productivity is to be obtained.

In south Florida where vast areas are used for grazing only, increasing the calving percentage offers most promise for improving the productivity of range herds. Providing about half the diet through the grazing of improved pasture in combination with wiregrass range offers one method of obtaining satisfactory percentages of calving and weaned weights.

Combined use of native and improved forages provides for greater flexibility in management of livestock and forage. For example, heavy use of pineland threeawn when palatable in the spring may be followed by a deferment of all grazing on native forages until seeds of the bluestems and other important native grasses mature; such a deferment should encourage a natural increase of the better grasses. The semitropical conditions of Florida favor use of a variety of forages to meet year-long herd requirements.

\section{Literature Cited}

Chapman, H. L., Jr., and W. G. Kirk. 1968. Management guide for cow-calf program in central and south Florida. Fla. Agr. Exp. Sta. Circ. S-192. 6 p.

Halls, L. K., O. M. Hale, and B. L. Southwell. 1956. Grazing capacity of wiregrass-pine ranges of Georgia. Ga. Agr. Exp. Sta. Tech. Bull. N.S. 2. $38 \mathrm{p}$.

Harlow, Richard F. 1961. Fall and winter foods of the Florida 
white-tailed deer. J. Fla. Acad. Sci. 24(1):19-38.

Hilmon, J. B. 1959. Determination of herbage weight by doublesampling: weight estimate and actual weight. p. 20-25. In Techniques and methods of measuring understory vegetation symposium proceedings 1958. Southern and Southeastern Forest Exp. Sta., Forest Serv., U.S. Dep. Agr.

Hilmon, J. B. 1964. Plants of the Caloosa Experimental Range. Forest Serv., U. S. Dep. Agr., Southeastern Forest Exp. Sta. Pap. SE-12. 24 p.

Hilmon, J. B., J. L. Clutter, and D. R. Cable. 1963. Layout of experimental units, p. 124-131. In Range research methods symposium 1962. U.S. Dep. Agr. Misc. Pub. 940.

Hilmon, J. B., and C. E. Lewis. 1962. Effect of burning on south Florida Range. Forest Serv., U.S. Dep. Agr., Southeastern Forest Exp. Sta. Pap. 146. 12 p.

Laessle, A. M., and O. E. Frye, Jr. 1956. A food study of the Florida bobwhite. J. Wildlife Manage. 20:125-131.

Leithead, H. L., L. L. Yarlett, and T. N. Shiflet. 1971. 100 native forage grasses in 11 southern states. U.S. Dep. Agr. Agr. Handbook 389. $216 \mathrm{p}$.

Lewis, C. E. 1964. Forage response to month of burning. Forest Serv., U.S. Dep. Agr., Southeastern Forest Exp. Sta. Res. Note SE-35. 4 p.

Parker, K. W. 1951. A method for measuring trend in condition on national forest ranges. Forest Serv., U. S. Dep. Agr., Washingtion,

\section{D.C. (Mimco)}

Parker, K. W., and R. W. Harris. 1959. The 3-step method for measuring condition and trend of forest ranges: a resume of its history, development and usc. p. 55-59. In Techniques and methods of Southern and Southeastern Forest Exp. Sta., Forest Serv., U.S. Dep. Agr.

Agr.

Pechanec, J. F., and G. D. Pickford. 1937a. A comparison of some methods used in determining percentage utilization of range grasses. J. Agr. Res. 54:753-765.

Pechanec, J. F., and G. D. Pickford. 1937b. A weight estimate method for determination of range or pasture production. Amer. Soc. Agron. J. 29:894-904.

Schemnitz, S. D. 1956. Wild turkey food habits in Florida. J. Wildlife Manage. 20:132-137.

Soil Conscrvation Service. 1962. Soil and capability map of Caloosa Experimental Range. Charlotte Soil Conserv. Dist., Soil Conserv. Serv., U.S. Dep. Agr., Punta Gorda, Fla.

Southwell, B. L., and R. H. Hughes. 1965. Beef cattle management practices for wiregrass-pine ranges of Georgia. Ga. Agr. Exp. Sta. Bull. N.S. 129. 26 p.

Wilm, H. G., D. F. Costello, and G. E. Klipple. 1944. Estimating forage yield by the double-sampling method. Amer. Soc. Agron. J. 36:194-203. 